\title{
Receiving and Action Oriented Attitude of the Youth Towards Mobile Marketing: A Transitional Economy Perspective
}

\author{
Mustapha Iddrisu $^{1}$, Akolaa Andrews Adugudaa ${ }^{1} \&$ Albert Martins $^{1}$ \\ ${ }^{1}$ Department of Marketing, Faculty of Management, University of Professional Studies, Accra, P.O Box LG.149 \\ Accra, Ghana \\ Correspondence: Mustapha Iddrisu, Department of Marketing, Faculty of Management, University of \\ Professional Studies, Accra, P.O Box LG.149 Accra, Ghana. E-mail: middris2010@gmail.com
}

Received: August 10, 2020

Accepted: September 16, $2020 \quad$ Online Published: November 9, 2020

doi:10.5539/ijms.v12n4p14

URL: https://doi.org/10.5539/ijms.v12n4p14

\begin{abstract}
The advancement in technology is influencing the ways in which organizations conduct business and marketing activities. Mobile Marketing has become one of the most widespread media to communicate with potential and existing customers mainly in the form of text advertisements through the internet. This study is aimed at finding out the receiving and action-oriented attitudes of the youth towards mobile marketing, particularly the rate at which the youth use mobile marketing to determine the propensity to be influenced in their actions. The study also investigated the factors affecting consumer attitudes and their relationship with mobile marketing. The study employed descriptive and exploratory research methodology design and the data were collected using a structured questionnaire. Four hundred (400) questionnaires were administered to young people between the ages of 18 and 35 years in Accra and Three hundred and fifty 350 were used. We found a high rate of youth's preference for mobile marketing messages and a relationship between youth attitude and mobile marketing messages and/or the youth's attitude being influenced by mobile marketing messages. Finally, it revealed that there is a relationship between the youth's receiving and action-oriented attitude and consumer factors that influence the use of mobile marketing.
\end{abstract}

Keywords: mobile marketing, youth's attitude, receiving-oriented attitude, action-oriented attitude

\section{Introduction}

Advancement in technology coupled with consumer sophistication, is driving the interest of many marketing strategists from traditional marketing towards digital marketing platforms such as mobile marketing to effectively influence the attitudes of relevant target markets. Channels of communication have been developed due to convenient devices such as mobile phones and tablets as well as social media which allow firms to construct a direct relationship with the customer (Van Bruggen et al., 2010). According to Nakano and Kondo (2018), a firm can "build an interactive relationship by providing product information through its own website or through social/new media platforms, such as Facebook and Twitter, in addition to traditional communication channels". According to Courtois et al., (2012) the use of media technologies by consumers is largely informed by three things, which are (1) objects, (2) texts, and (3) the social and physical environment.

Consumers behave differently to different forms of communications from organizations. Robbins and Judge (1999) defined consumer attitude as an evaluative statement - either favorable or unfavorable - concerning objects, people, or events. Attitude is not observable, it only manifests in behavior towards a product, service, object or a person and therefore attitude research is important for marketers since attitude influences behavior. Lars (2010) defined consumer attitude as a combination of consumers' beliefs, behavioral intentions and feelings toward an object within marketing practices. Therefore, behavioral intentions can be determined in the rate at which a person is willing to use new information technology (Tsai, 2012).

Mobile marketing, is defined by Shankar and Balasubramanian (2009, p. 118) as "the two-way or multi-way communication and promotion of an offer between a firm and its customers using a mobile medium, device, or technology". The concept has become an integral part within the digital marketing landscape (Lamberton and Stephen, 2016). Mobile marketing has been characterized by Grewal et al., (2016, p. 14) as providing "new opportunities for targeting" in order to communicate aiming at "grabing [a] particular consumer's attention and move him/her closer to a purchase". It can therefore be argued that in an attempt to trigger the purchase of goods 
and services, mobile media is one effective and efficient means to do this. Scholz and Duffy (2018) argued that consumers are rather seen as mere target for information, and that they in turn have to adopt an approach that is transactional towards mobile shopping, centered on prices checking and searching for bargains (Fuentes and Svingstedt, 2017).

Varshney and Joy $(2015$, p. 44) looked at mobile marketing to be "characterized as offering information of goods, services, and ideas to customers for promoting them by using mobile phones". The youth is a critical market for marketers because of their buying power and influence on the spending of other family members. Mobile phones have become a part of the youth and most people all over the world. Today, anecdotal evidence suggests that the youth have an "intimate relationship" with their mobile phones. This is because when a youth wakes up from sleep; the first thing she/he comes into contact with is the mobile phone to check out messages, what is trending on social media, especially for smartphones users. Marketers have realized they can connect easily with the youth any time through their phones (Okazaki, 2009) hence marketers have adopted mobile marketing as a strategic medium to communicate with the target consumers.

The mobile marketing services have an extensive context of electronic services with a positive effect on society and thus can lead to higher productivity and enhance growth of an organization (Balan and Zegreanum, 2012). There is a wide range of platforms in technology that is used to support mobile marketing applications. These include Wireless Application Protocol (WAP) and Short Message Service (SMS) (Carrol et al., 2007).

According to Hopkins and Turner (2012) although there is heightened excitement about mobile marketing, practitioners will be surprised how many people talk about mobile marketing but don't actively use it. The lack of active application of mobile marketing may result from consumer issues with uncertainty, trust and beliefs (Kaan Varnali, 2012). Previous research on mobile marketing have largely dwelt on the concept in retailing locations and public space (e.g., Hui et al., 2013; Ghose et al., 2015; Shankar et al., 2016; Andrews et al., 2016; Verhoef et al., 2017).

Despite the growth of mobile phone penetration as a result of faster, easier and more effective communications, with an increased demand for mobile marketing (Amen, 2010) and number of companies investing in it is increasing towards the youth, studies have not adequately explored the youth's attitude towards this new marketing communication tool, especially in emerging economies. Customers' attitude and behavioral intentions towards mobile marketing messages remain somewhat missing in existing literature. Thus a study of the attitude and behavioral intentions of the youth towards mobile marketing and investigating the influence of mobile marketing on the youth in a transitional economy such as Ghana is very crucial.

This study investigated the attitude of the youth towards mobile marketing. Based on the Theory of Reasoned Action (TRA) (Fishbein and Ajzen, 1975) and the Theory of Planned Behavior (Ajzen, 1985, 1991) which are combined for this study, attitude can be either action-oriented or receiving-oriented. This study's contribution to knowledge is that it identified that consumer attitude towards mobile marketing should not be looked at as just attitude but as receiving and action-oriented attitude.

The organization of the paper is as follows: In the first place, hypotheses and a framework are developed through the review of relevant literature on factors that influence attitude towards mobile marketing. Secondly, the hypotheses tested the influence of Entertainment, Innovativeness, Credibility, Privacy and Permission, Perceived Risk, Perceived Value and Customer's Existing Knowledge on the youth's attitude. Thirdly, the results of the study are analyzed using Structural Equation Modelling (SEM). Finally, a conclusion is drawn with the results discussed and implications for both managers and scholars indicated, as well as the limitations for further studies stated.

\section{Review of Relevant Literature}

\subsection{The Concept and Definition of Mobile Marketing}

Business owners are now looking out for new directions in the era of technological advancement and new strategies of communication so as to respond to the increasing number of mobile devices (Nakano and Kondo, 2018). Marketers use mobile marketing as a strategic tool in communicating with their consumers. Research on mobile marketing has shown that specialists and academics have given various definitions to mobile marketing, but these scholars have not come into agreement in their definitions. The Mobile Marketing Association (2007) defines mobile marketing as a "set of practices that enables organizations to communicate and engage with their audience in an interactive and relevant manner through any mobile device or network". Can we consider other definitions to be clear that there is indeed no agreement? 


\subsection{Mobile Marketing Techniques}

There are a number of technological tools that have been identified to facilitate mobile marketing communications. The techniques that have stood out over the past decade in mobile advertising which uses Multimedia Messaging Services (MMS) and Short Messaging Services (SMS) that reach a wide range of customers at a time (Zabadi, et al., 2012; Katz, 2013, p. 33; Latto, 2014; Hong and Im, 2018) include, mobile entertainment that allows consumers to listen to and download music, videos, movies and play games is increasing in popularity (Ghyas and Kondo, 2018; Kondo and Ishida, 2014). Another technique worth mentioning is mobile sales promotion which is being used to target customers close and far away as well as those closer to competitors using mobile coupons (Luo et al., 2014; Fong et al., 2015; Andrews et al., 2016; Ghose et al., 2018). Mobile internet with the use of smart phones which has taken over personal computers has gained grounds in the delivery of marketing communications to customers far and wide (Canalys, 2012; Arthur, 2013) is one good mobile marketing techniques. Techniques such as location-based mobile services (Rosenblatt, 2016; Wu and Stilwell, 2018); mobile shopping (Martin, 2013; Mangold, et al., 2018) and mobile banking which gives customers the opportunity to access banking services anytime anywhere (Baptista and Oliveira, 2015; Koksal, 2016; Poddar et al., 2016; Agwu and Carter, 2018) is equally crucial. Other mobile marketing techniques that have come up lately include Augmented Reality (AR) and Virtual Reality (VR). Augmented Reality (AR) is defined by Carmigniani and Furht (2011, pp. 341-377) as "the practice of augmenting a real-time direct or indirect view of the physical world with virtual information". AR marketing has also been defined by Rauschnabel and Hinsch (2019, pp. 43-53) as "a strategic concept that integrates digital information or objects into the subject's perception of the physical world, often in combination with other media, to expose, articulate, or demonstrate consumer benefits to achieve organizational goals". In the contemporary world, consumers' mobile devices are used for AR (Yim et al., 2017; Hilken et al., 2017; Poushneh and Vasquez-Parraga, 2017; Poushneh, 2018). Virtual Reality (VR) looked at by Steuer (1992) who framed virtual reality as "a real or simulated environment in which a perceiver experiences telepresence". VR was defined later as "the experience of presence in an environment by means of a communication medium" (p. 76). Brooks (1999) gave a more comprehensive definition of VR as "the user is effectively immersed in a responsive virtual world in a way that allows a dynamic control over his or her viewpoint" (p. 16). Berg and Vance (2016) positioned VR as an immersive technology in computing (ICT) - as a "set of technologies that enable people to immersive experience of a world beyond reality and engage in human encounters that mimic their own interpretation of the world around them" (p. 1). JBR Special issues (2019, pp. 441-444) proposed the following definition: "Virtual reality incorporates computer-generated, interactive and highly vivid environments that enable the user to achieve a state of immersion through the ultimate experience of telepresence, and facilitate engagements in human encounters that are multi-sensorial, dynamic and resemble the user's perception and understanding of the real world." It is clear that the implementation of mobile marketing techniques has become increasingly valuable for both retailers and customers (Ström and Vendel, 2014).

\subsection{Factors Influencing Attitude Towards Mobile Marketing}

There are a number of factors influencing attitude towards mobile marketing. Some of which include entertainment, credibility and innovativeness. There are also many mobile apps available used to provide information, music, videos, games and social media (Logan, 2017). In a study conducted by Persaud and Azhar (2012) on mobile marketing via smartphones among Canadian consumers, certain key factors such as brand trust, perceived value, age and education, shopping style had influence on customer intention to partake in mobile marketing. Consumers' feeling to control the efficient selection and processing of marketing communication is key, as they take a more reliable connection and experience and assimilate with other cultural influences (Banerjee and Longstreet, 2016) especially in mobile communications.

\subsubsection{Entertainment}

McQuail (1983, pp. 93-111) defines entertainment as "the ability to fulfill an audience's needs for escapism, diversion, or aesthetic or emotional enjoyment". For mobile marketing communications to be effective, one technique that can be used is entertainment. Entertainment according to Sheth and Kim (2017) is one of the most important reasons for the use of social media. They can communicate, chat, conduct surveys, form groups, upload and download music, videos, or pictures and can use other features for purposes of entertainment. Meaning, entertainment enjoys a universal appeal. Attitude towards mobile marketing has a significant relationship with entertainment (Raines, 2013). According to Sigurdssona, et al., (2017) entertainment remains the major factor that affects attitudes in most countries. There is also an argument that entertainment and mobile marketing have a strong relationship (Haron et al., 2015). Therefore, we hypothesize that: 
$\mathbf{H}_{1:}$ There is a relationship between mobile entertainment and the youth's action and receiving oriented attitude towards mobile marketing in Ghana.

\subsubsection{Perceived Risk}

Perceived risk is defined by Mayer et al., (1995) as the likelihood of both positive and negative outcomes of trust. In explaining consumer' behavior, Perceived risk comes in strongly because according to Mitchell $(1999$, p. 163) "consumers are more often motivated to avoid mistakes than to maximize utility in purchasing". Perceived risk is very important when it comes to attitude towards mobile marketing and customers regard the risk involved in transacting a business especially when they are not sure of what they are dealing with. A study by Laforet and Li (2005) that investigated consumers' attitude towards mobile and online banking in China indicated perceived risks as the main reason for internet banking rejection. This indicates that where consumer perceived risk is high, it will negatively impact mobile marketing acceptance and where the consumer perceived risk is low, it will positively affect mobile marketing acceptance. Masamila (2014) identified amongst other obstacles of perceived risk such as viruses and malware, data protection and privacy, risk of PIN protection as well as the fear of harassment negatively affecting the acceptance rate of mobile banking in Tanzania. This finding is consistent with the study of Laforet and $\mathrm{Li}$ (2005) who found that customers with less knowledge in technology will not risk venturing into what they are not aware of.

Rumanyika (2015) also found that the lack of understanding of mobile banking operations, mobile-related transactions and perceived risk are keys in preventing the adoption of mobile marketing. Richard and Mandari (2018) established that perceived risk has a negative influence on mobile marketing. The lower the perceived risk of an object, the more likely it is to be adopted, and vice versa (Evans et al., 2006). Hence, we hypothesize that:

$\mathbf{H}_{2}$ : There is a relationship between perceived risk and the youth's action and receiving oriented attitude towards mobile marketing.

\subsubsection{Perceived Value}

Ström, et al., (2014) describes value as 'the overall benefit offered by products or services in comparison to customer sacrifices to acquire and use such product or service relative to existing competition'. Liu et al., (2012) defined perceived value in mobile advertising as "the subjective evaluation of the worth or utility of advertising." Lee and Jun (2007) defined contextual perceived value as "the degree to which a person believes that receiving context-relevant information or services would enhance his or her purchase performance" Considering consumers perception of the value of a marketing tool, those perceptions might be seen to be a major component when it comes to building a competitive advantage of the firm and can be used to determine buying intention (Chang and Tseng, 2013). In this regard, the mobile marketing value is the customer's perceived judgment about the communication and that can be a measure of the customer satisfaction of a firm's products and services. The value of the communications sent must be perceived to be very encouraging.

$\mathbf{H}_{3}$ : There is a relationship between perceived value and the youth's action and receiving oriented attitude towards mobile marketing.

\subsubsection{Innovativeness}

Mobile marketing is a strategy used by marketers as a marketing instrument for communicating with consumers. These marketing instruments are influenced by consumers' degree of innovativeness. These consumers like to explore and experiment new technologies by learning how to use these technologies. Jang and Lee $(2018$, p. 10) defined personal innovativeness as "the willingness of an individual to try any new technology". There are individuals who are always ready to take the risk of uncertainty and such people display high level innovativeness and will be ready to experiment with new technology. Innovativeness is also observed by Jang and Lee (2018, p. 11) as a moderating factor for consumer attitudes. There is also evidence in the literature to show that innovativeness has a relationship with consumer attitude (Jeong, et al., 2009). Therefore, we hypothesize that:

$\mathbf{H}_{4}$ : There is a relationship between innovativeness and the youth's action and receiving oriented attitude towards mobile marketing.

\subsubsection{Credibility}

Credibility, according to MacKenzie and Lutz (1989, pp. 48-65) is "the extent to which the consumer perceives claims made about the brand in the advertisement to be truthful and believable". This means that for mobile marketing to be accepted it must be credible because according to Lin and Bautista (2018), credibility has two 
sides: "advertising credibility (i.e., how the actual information in the advertisement is perceived to be truthful or credible) and advertiser credibility (i.e., the extent by which consumers perceive a company as a credible source of information)" and their study recognized the relationship between credibility and consumers intention or attitude. Other researchers posited that credibility has a positive relationship with advertising value (Liu et al., 2012), and attitudes towards online, traditional and mobile advertisements (Xu, 2006). Sigurdsson et al., (2017) found that credibility is related to attitudes in advanced countries but not necessarily in emerging countries. Trust is closer to credibility and is one the most important components worth considering in mobile marketing. Because mobile marketing tools are usually felt on face to face but rather on virtual arena, there is the need to build consumer confidence, and trust is one of the ways to build that. Due to the significance of trust, it received a high-level attention in research over the years especially in information systems example (Beldad et al., 2010; Li et al., 2012). When consumers develop trust in mobile marketing, they will believe that the service, what it takes to work with, and thereby mitigating perceived risk. Researches in the past have indicated the value of trust in driving mobile marketing. Kushwaha and Shankar (2013) for example found the influence of trust on customers' choice of mobile marketing tools. Thongpapanl, et al., (2018) have also found a positive relationship between trust and some mobile marketing tools as well as the attitude of consumers. Thus;

$\mathbf{H}_{5:}$ There is a relationship between credibility and the youth's action and receiving oriented attitude towards mobile marketing.

\subsubsection{Privacy and Permission}

Privacy issues have become topical in recent times in both practice and academia. Consumers all over the globe are more concerned about their privacy when downloading apps from the internet or navigating on the browser. Privacy decision making issues have been considered in the literature because of the concerns and risks of giving out information about one's self (Nikkhah and Sabherwal, 2017). There are also issues surrounding data sharing with privacy concerns (Gopal et al., 2018). Individual decision-making should come with the opportunity to consent and to make choices as it is argued by Solove (2012) and Acquisti et al., (2015). As matter of fact, individuals are not aware of how their personal data is shared (Belanger and Xu, 2015, p. 576). Lai et al., (2018) have argued that once an app is requesting for more permissions, it can result in negative attitudes by consumers. They also contended that the privacy-level of the permissions requested have a positive effect on the perception of users regarding the privacy risk. They also indicated that the higher the permissions requested, the higher the users' perception of privacy risk.

There is a close relationship between spam and privacy invasion and that it should be defined from the viewpoint of the customer. Therefore, marketing should define spam as any message that the recipient sees as unsolicited or unwanted. The consumer should therefore be given the opportunity to receive messages they would like to receive or otherwise and when they choose to receive the message. The personal nature of devices make issues of privacy more sensitive especially when it comes to mobile marketing. Explicitly, consumers' permission is critical for a high degree of acceptance and satisfaction of mobile marketing and that consumers generally have a negative attitude to unsolicited mobile advertising messages.

$\mathbf{H}_{6}:$ There is a relationship between permission and privacy and the youth's action and receiving oriented attitude towards mobile marketing.

\subsubsection{Existing Knowledge of Mobile Services}

One of the factors that can affect consumer attitude towards a product is customer prior-knowledge of the products. Users' knowledge of the insecurity of the mobile marketing tools (Liu, 2015) is very important in determining what the consumer chooses. Customers' existing knowledge of a product or service enhances its acceptability. When customers have prior knowledge, the service usage becomes easier and adoption also becomes easier. Asongu and Nwachukwu (2018) argued that in Sub-Saharan Africa where there is low literacy rate, quality education is key for the customer to understand technology diffusion and that is made easier by existing knowledge. Okello et al., (2018) found a positive relationship between knowledge and information sharing of mobile phone users and poverty where they argued that the poor largely depend on their close families for information and knowledge on mobile usage. Asongu and Nwachukwu (2016) found that Knowledge after beyond basic education to be positively related to mobile phones use. Asongu and Nwachukwu (2018) also indicate that quality education positively affects inclusive human development and mobile phones use.

$\mathbf{H}_{7}$ : There is a relationship between customer existing knowledge and the youth's action and receiving oriented attitude towards mobile marketing. 


\subsection{Consumer Attitude}

Today's consumers prefer making informed decision on purchases based on available information on the products or services; they then evaluate the alternatives as well as undertaking a cost-benefit analysis (Sheth and Kim, 2017). Consumer behavior includes mental, physical and emotional activities that potential consumers go through or use when they want to select, purchase, use or dispose off the product or service (Jeddi, et al., 2013). Knowing these attitudes help marketers to get familiar with the way costumers think and feel, as well as the way they choose various brands, products and services or how the environment, reference groups, family, vendors, etc. can affect them (Abdul et al., 2013). Understanding consumer buying behavior can help marketers get more familiar with their customers; moreover, it could be the basis for marketers to develop appropriate marketing strategies. One of the major factors in marketing and information systems is attitude (Tsang, et al, 2004). However, the case may differ in advertising mobile and marketing. Abrams (2013) argued that the increasing nature of sophisticated mobile devices, such as smartphones, has led to more powerful consumers who have shopping centers on the tip of their hands. Attitude can be either action oriented or receiving oriented. Hassan et al., (2014, p. 220) in reviewing ethics of consumers, contrasted between intention, attitude and behavior, having argued in that research that "identified gaps exist between what consumers think, what they intend and what they actually do". Literature has found two main theories, including the theory of reasoned action (Fishbein and Ajzen, 1975) and the theory of planned behavior (Ajzen, 1985, 1991), which dominate discussions surrounding attitudes (individual thinking), the intention (individual intention), and behavior (individual actually action). These theories suggest that an individual's behavior comes from the intention to act in a certain manner and that such intentions are influenced by the attitude toward the behavior.

\section{Theoretical and Conceptual Framework}

The study adopted the theory of reasoned action (TRA) (Fishbein and Ajzen, 1975) and the theory of planned behavior (Ajzen, 1985, 1991) as well as researchers own conceptualization. The theory of reasoned action is used in this current study for the action-oriented attitude of the youth whilst the theory of planned behavior is used for the receiving oriented attitude. In this study, it is conceptualized that seven main indicators will influence consumers' attitude towards mobile marketing including Entertainment, Innovativeness, Credibility, Privacy and Permission, Perceived Risk, Perceived Value and Customer's Existing Knowledge.

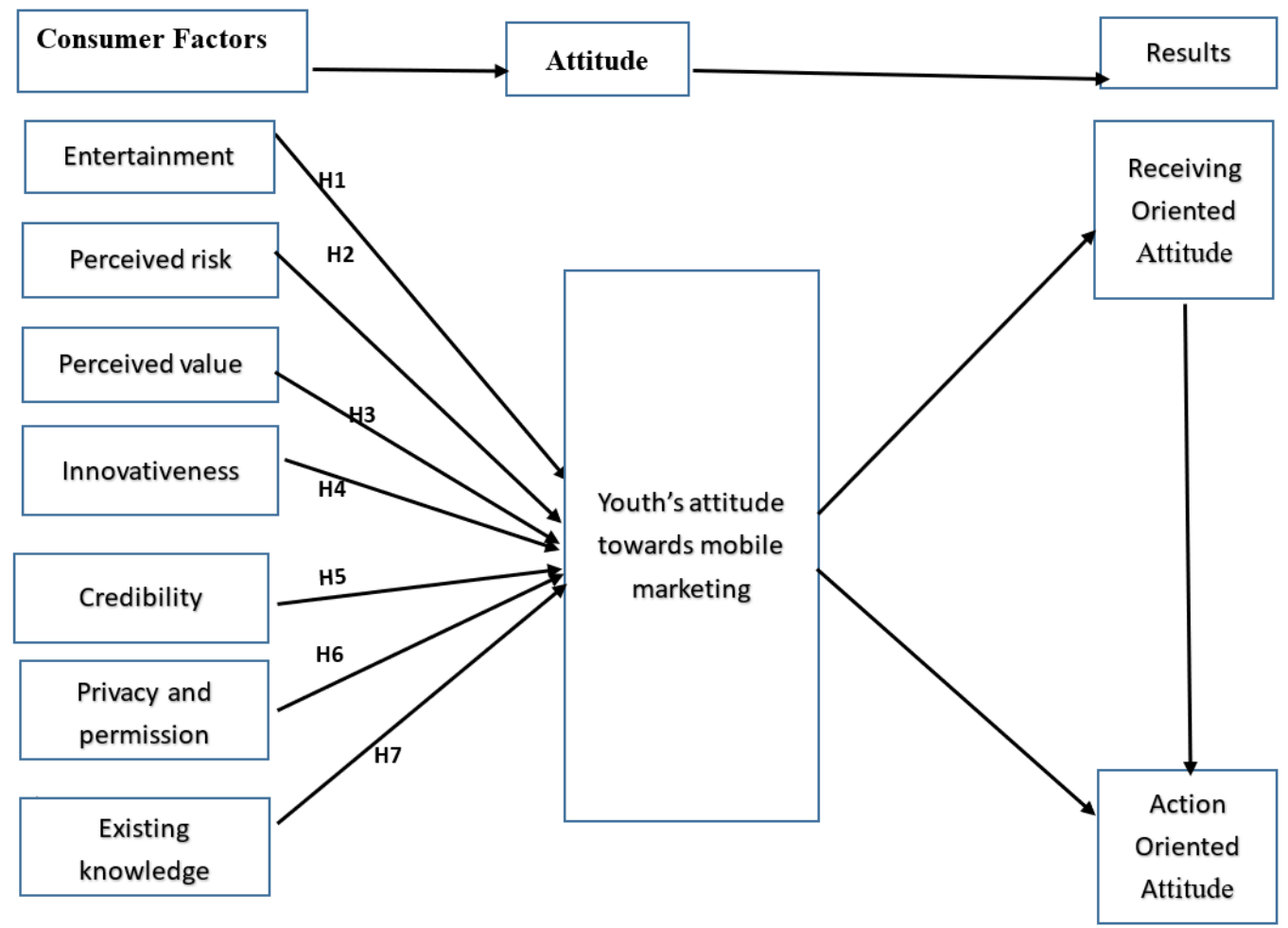

Figure 1. Conceptual framework 


\section{Methodology}

The study adopted a quantitative research method to gauge the attitude of the youth towards mobile marketing. The attitude was examined on two spheres including receiving oriented attitude and action-oriented attitude. The instrument used for the study was adopted from previous studies of (Salem, 2016; Ryu, 2013) and adapted to suit the current study.

The sample group for this study constituted students from the Business Schools or Faculties of Managements from five universities in Accra, made up of two public and three private universities located with close proximity to each within the eastern part of the city with different categories of people (Shapiro et al., 2013). The two public universities had a student population of 8000 in their business schools while the three private universities had a population of 2000 students in their business faculties together. The reason for selecting these groups of students was because majority of them are very youthful with ages ranging between 18 and 35 and are the group that are seen to be mobile device and technology savvy. A total of 400 questionnaires were sent out to the target respondents with 380 returning. When the questionnaire was cleaned, only 350 were used for analysis. Gender and Age are expressed by dummy variables. Age and study level, and programme of study, were expressed as continuous variables. Table 1 represents the summary statistics of demographic covariates. The study is intended to identify the kind of messages respondents are comfortable with and their respective level of agreement to the various marketing messages, as well as find the relationship between the constructs and the consumer attitudes. Data was collected using a questionnaire. A five (5)-point Likert Scale with responsive anchors with the following ranges: 1 representing "Strongly Disagree", 2 being "Disagree", 3 being "Undecided", 4 representing "Agree" and 5 representing "Strongly Agree" was used.

Table 1. Summary statistics of demographic covariance

\begin{tabular}{llll}
\hline Gender & \multicolumn{3}{c}{ Level } \\
Male & 47.7 & 100 & 23.43 \\
Female & 52.3 & 200 & 24.29 \\
Age & & 300 & 16.29 \\
18 and below & $21.7 \%$ & 400 & 36 \\
$19-24$ & $71.4 \%$ & Programme of study & \\
$25-34$ & $6.9 \%$ & Marketing & 30.6 \\
& & Banking \& Finance & 28.9 \\
& & Accounting & 22.9 \\
& & HR/ Business Administration & 17.7 \\
\hline
\end{tabular}




\section{Results}

Table 2. CFA

\begin{tabular}{|c|c|c|}
\hline Details & Loadings & T-value \\
\hline \multicolumn{3}{|l|}{ Receiving oriented attitude } \\
\hline I like to receive mobile messages of products/services on price discounts & 0.562 & 10.184 \\
\hline I like to receive mobile messages of products/services granting me free access to downloads & 0.617 & 11.397 \\
\hline I like to receive mobile adverts of products/services which are relevant to my need & 0.864 & 17.292 \\
\hline I like to receive mobile adverts of products/services to which i personally subscribe & 0.742 & 14.283 \\
\hline \multicolumn{3}{|l|}{ Action oriented attitude } \\
\hline I am interested in buying product/services that meet my need & 0.643 & 12.131 \\
\hline I will buy a product/service introduced to me in a mobile advert & 0.799 & 16.177 \\
\hline I will respond to a mobile messages' promotion sent to my phone & 0.649 & 12.258 \\
\hline I do use mobile messages to get information that i need & 0.733 & 14.386 \\
\hline I have purchased a product/service after receiving a mobile advert & 0.688 & 13.231 \\
\hline \multicolumn{3}{|l|}{ Innovativeness } \\
\hline I like to experiment with new mobile phone technology & 0.887 & 22.809 \\
\hline I learn fast on how to use new mobile phone services & 0.915 & 22.809 \\
\hline \multicolumn{3}{|l|}{ Existing knowledge of mobile technology } \\
\hline I have a good knowledge about mobile communication & 0.657 & 10.32 \\
\hline It is easy for me to use mobile phone services & 0.790 & 11.788 \\
\hline \multicolumn{3}{|l|}{ Privacy and permission } \\
\hline It is important for me that I can easily stop receiving mobile messages when I choose to & 0.779 & 12.719 \\
\hline I will give my permission to receive mobile messages that are relevant to me & 0.861 & 13.782 \\
\hline \multicolumn{3}{|l|}{ Credibility } \\
\hline I like to receive mobile adverts of product/service from companies that I know & 0.675 & 11.505 \\
\hline I like to receive mobile adverts of product/service sent by an established brand & 0.862 & 14.22 \\
\hline \multicolumn{3}{|l|}{ Perceived risk } \\
\hline I fear my personal data can be misused when using mobile marketing services & 0.887 & 11.372 \\
\hline Some unwanted mobile messages could come to me when using mobile marketing services & 0.768 & 10.518 \\
\hline \multicolumn{3}{|l|}{ Perceived value } \\
\hline I find mobile messages as a good source of up-to-date sales information & 0.776 & 13.322 \\
\hline I see mobile messages as a good source of getting latest news & 0.694 & 12.032 \\
\hline \multicolumn{3}{|l|}{ Entertainment } \\
\hline I find mobile phone entertainment services interesting & 0.897 & 15.258 \\
\hline I find mobile messages of product/services entertaining & 0.671 & 11.724 \\
\hline
\end{tabular}

Table 3. Model fit measures

\begin{tabular}{llll}
\hline Measure & Estimate & Threshold & Interpretation \\
CMIN & 400.452 & -- & -- \\
DF & 195 & -- & -- \\
CMIN/DF & 2.054 & Between 1 and 3 & Excellent \\
CFI & 0.926 & $>0.95$ & Acceptable \\
SRMR & 0.052 & $<0.08$ & Excellent \\
RMSEA & 0.057 & $<0.06$ & Excellent \\
PClose & 0.079 & $>0.05$ & Excellent \\
\hline
\end{tabular}

\subsection{Measurement of Model}

In order to measure the fitness of model, Confirmatory Factor Analysis (CFA) was undertaken with the Amos 21. Also, factor loadings of the items and constructs validity were assessed. The Comparative Fit Index (CFI) is 0.926, a Standardized Root Mean Square Residual (SRMR) was 0.052 whilst the Root Mean Square Error Of Approximation (RMSEA) was 0.057. All the fitness test measured had the acceptable threshold (Hu and Bentler, 1999; Bagozzi and Yi, 2012) (Table 3). Each of the factor loadings were above 0.60 without any cross loadings whilst the construct validity using the t-values were all acceptable (Table 2). This indicates that measurements of the model fitness achieved both discriminant and convergent validity and are also without method bias that are common (Bagozzi and Yi, 2012).

Again, the values for the Composite Reliability (CR) are acceptable. Average Variance Extracted (AVE) values 
(Table 4) show that only CC (Receiving oriented attitude) and DD (Action oriented attitude) did not meet the acceptable threshold whilst all the other factors were acceptable (Malhotra and Dash, 2011; Bagozzi and Yi, 2012). This means that the measurement is acceptable; therefore, further analysis could be conducted. In Table 4, an inter-construct correlation shows that each one seen in the diagonal indicate that all the constructs are highly significant such as 0.946 (INN), 0.741 (EKM), 0.821 (PAP), 0.774 (CRE), 0.829 (PRI), 0.734 (PVV) and 0.793 for (ENT) using correlation significant level of 0.01 and 0.05 .

Table 4. Inter-construct correlations

\begin{tabular}{llllllllllll}
\hline & CR & AVE & CC & DD & INN & EKM & PAP & CRE & PRI & PVV & ENT \\
\hline CC & 0.795 & 0.499 & $\mathbf{0 . 7 0 6}$ & & & & & & & \\
DD & 0.831 & 0.497 & 0.318 & $\mathbf{0 . 7 0 5}$ & & & & & & \\
INN & 0.942 & 0.894 & 0.112 & 0.103 & $\mathbf{0 . 9 4 6}$ & & & & & \\
EKM & 0.703 & 0.549 & -0.047 & 0.045 & 0.450 & $\mathbf{0 . 7 4 1}$ & & & & \\
PAP & 0.805 & 0.675 & 0.199 & 0.188 & 0.185 & 0.321 & $\mathbf{0 . 8 2 1}$ & & & \\
CRE & 0.747 & 0.600 & 0.332 & 0.337 & 0.184 & 0.101 & 0.420 & $\mathbf{0 . 7 7 4}$ & & \\
PRI & 0.814 & 0.687 & 0.130 & 0.021 & 0.121 & 0.126 & 0.185 & 0.347 & $\mathbf{0 . 8 2 9}$ & \\
PVV & 0.701 & 0.539 & 0.338 & 0.502 & 0.125 & 0.139 & 0.040 & 0.332 & -0.043 & $\mathbf{0 . 7 3 4}$ & \\
ENT & 0.769 & 0.629 & 0.176 & 0.519 & 0.092 & 0.008 & 0.103 & 0.311 & 0.009 & 0.622 & $\mathbf{0 . 7 9 3}$ \\
\hline
\end{tabular}

Note. Diagonal values denote the AVE variables whilst the other values indicate the inter-construct correlations.

** Correlation is significant at the 0.01 level (2-tailed).

* Correlation is significant at the 0.05 level (2-tailed).

Table 5. Test of hypothesis

\begin{tabular}{|c|c|c|c|c|c|}
\hline Details & & & Estimate ( $\beta$ ) & t-value & P-value \\
\hline \multicolumn{6}{|l|}{ Path } \\
\hline Innovativeness & $-->$ & Receiving oriented attitude & 0.128 & 2.293 & 0.022 \\
\hline Existing knowledge & $-->$ & Receiving oriented attitude & -0.139 & -2.465 & 0.014 \\
\hline Privacy and permission & $-->$ & Receiving oriented attitude & 0.118 & 2.127 & 0.033 \\
\hline Credibility & $-->$ & Receiving oriented attitude & 0.131 & 2.243 & 0.025 \\
\hline Perceived risk & $-->$ & Receiving oriented attitude & 0.04 & 0.747 & 0.455 \\
\hline Perceived value & $-->$ & Receiving oriented attitude & 0.233 & 3.981 & $* * *$ \\
\hline Entertainment & $-->$ & Receiving oriented attitude & 0.026 & 0.447 & 0.655 \\
\hline Privacy and permission & $-->$ & Action oriented attitude & 0.087 & 1.705 & 0.088 \\
\hline Credibility & $-->$ & Action oriented attitude & 0.103 & 1.898 & 0.058 \\
\hline Privacy risk & $-->$ & Action oriented attitude & -0.043 & -0.873 & 0.383 \\
\hline Perceived value & $-->$ & Action oriented attitude & 0.166 & 3.026 & 0.002 \\
\hline Entertainment & $-->$ & Action oriented attitude & 0.3 & 5.687 & $* * *$ \\
\hline Innovativeness & $-->$ & Action oriented attitude & 0.063 & 1.219 & 0.223 \\
\hline Existing knowledge & $-->$ & Action oriented attitude & -0.053 & -1.012 & 0.311 \\
\hline Receiving oriented attitude & $-->$ & Action oriented attitude & 0.16 & 3.158 & 0.002 \\
\hline \multicolumn{6}{|l|}{ Control variables } \\
\hline Gender & $-->$ & Receiving oriented attitude & -0.036 & -0.697 & 0.486 \\
\hline Age & $-->$ & Receiving oriented attitude & 0.041 & 0.791 & 0.429 \\
\hline Level of study & $-->$ & Receiving oriented attitude & -0.079 & -1.545 & 0.122 \\
\hline Gender & $-->$ & Action oriented attitude & 0.057 & 1.212 & 0.225 \\
\hline Age & $-->$ & Action oriented attitude & -0.015 & -0.307 & 0.759 \\
\hline Level of study & $-->$ & Action oriented attitude & 0.053 & 1.123 & 0.261 \\
\hline
\end{tabular}

In testing the hypothesis, the researchers adopted path analysis for all the consumer constructs with receiving oriented attitude and action-oriented attitude. The values obtained from the receiving oriented attitude and the constructs indicated perfect estimates $(\beta)$ of $0.128,0.139,0.118,0.131,0.04,0.233$ and 0.026 for Innovativeness (INN), Existing knowledge of mobile technology (EKM), Privacy and Permission (PAP), Credibility (CRE), Perceived Risk (PRI), Perceived Value (PVI) and Entertainment (ENT) respectively.

\subsection{Structural Equation Modelling}

SEM was conducted for the evaluation of the research model and tested the hypotheses. The model fit was good: with a threshold of $>0.05$ and p-value $<0.001$; CFI of 0.974; and SRMR of 0.038; RMSEA of 0.039 and PClose of 0.716 as shown in Table 6 . The results for statistical significance are shown Table 4 with the standardized path coefficients shown in Table 5 . 
Entertainment had a significant positive effect on the youths' receiving and action-oriented attitude towards mobile marketing and that supports both hypothesis $1(\beta=0.026$, t-value $=0.447$, $p$-value $=0.655)$ and $2(\beta=0.3$; $\mathrm{t}$-value $=5.687 ; \mathrm{p}$-value $=0.000)$. Therefore, we accepted hypothesis 1 whiles hypothesis 2 was rejected; here we used only the t-values and this supports the arguments by Raines (2013); Sigurdssona, Vishnu, Menon, Hallgr, Larsen and Fagerstrøm (2017) and Haron et al., (2015).

For hypotheses 3 and 4 which were related to perceived risk, the analysis revealed a strong relationship for the receiving oriented attitudes of the youth $(\beta=0.04$, t-value $=0.747$, $p$-value $=0.455)$ and action oriented attitudes showed negative relationship $(\beta=-0.043$, $\mathrm{t}$-value $=-0.873$, $\mathrm{p}$-value $=0.383$ ) supporting Richard and Mandari (2018) who established that perceived risk has a negative influence on mobile marketing, therefore, hypothesis 3 was accepted though it was not supported by Richard and Mandari (2018). Hypothesis 4 was however rejected.

The study also established the positive effects of perceived value on the receiving and action-oriented attitudes of the youth towards mobile marketing which supported hypothesis $5(\beta=0.233$, t-value $=3.981$, $p$-value $=0.000)$ and $6(\beta=0.166, \mathrm{t}$-value $=3.026$, $\mathrm{p}$-value $=0.002)$ was rejected because all the values showed significant relationship.

Innovation positively influence the youths' receiving and action-oriented attitude towards mobile marketing and this supports Hypotheses $7(\beta=0.128, \mathrm{t}$-value $=2.293$, $\mathrm{p}$-value $=0.022)$ and $8(\beta=0.063$, $\mathrm{t}$-value $=1.219$, $\mathrm{p}$-value $=0.223$ ) confirming the study of Jeong, Yoo and Heo (2009) which indicated a positive relationship between and innovation and consumer behaviour. Thus hypotehsis 7 was accepted whiles the alternative was rejected.

Credibility had significant influence on both the receiving and action-oriented attitudes towards mobile marketing $(\beta=0.131$, $\mathrm{t}$-value $=2.243$, $\mathrm{p}$-value $=0.025)$ and $(\beta=0.103$, $\mathrm{t}$-value $=1.098, \mathrm{p}$-value $=0.058)$ respectively. This indicates that hypothesis 9 is accepted while hypothesis 10 is rejected. This supports the studies by Kushwaha and Shankar (2013); and Thongpapanl, Ashraf, Lapa and Venkatesh (2018) who argued that there exists a positive relationship between credibility and some mobile marketing tools as well as the attitude of consumers.

Privacy and permission had significant positive influence on both the receiving and action oriented with values $(\beta=0.118, \mathrm{t}$-value $=2.127, \mathrm{p}$-value $=0.033)$ and $(\beta=0.087, \mathrm{t}$-value $=1.705, \mathrm{p}$-value $=0.088)$. This shows that hypothesis 11 was accepted and hypothesis 12 was rejected. Since the attitudes here are positive it does not support the argument by Lai, Hsu and $\mathrm{Wu}$ (2018) who opined that once an app is requesting for more permissions, it can result in negative attitudes by consumers.

Existing knowledge of mobile services recorded a negative influence on both the receiving and action-oriented attitude of the youth towards mobile marketing. As the figures show hypothesis 13 ( $\beta=-0.139$, $t$-value $=-2.465$, $\mathrm{p}$-value $=0.014)$ and hypothesis $14(\beta=-0.053$, $\mathrm{t}$-value $=-1.012$, $\mathrm{p}$-value $=0.311)$. This indicated that hypothesis 13 was rejected while the alternative (hypothesis 14 ) was accepted.

The study also established that there is a positive relationship between receiving oriented attitude and action-oriented attitude with $(\beta=0.16$, t-value $=3.158$, $p$-value $=0.002)$, an indication of strong influence.

The control variables that were used include gender, age and level of education. For receiving oriented attitude both gender and Level of study recorded negative figures with $(\beta=-0.036$, t-value $=-0.697, \mathrm{p}$-value $=0.486)$ and $(\beta=-0.079, \mathrm{t}-\mathrm{value}=-1.545, \mathrm{p}$-value $=0.122)$ respectively, showing no impact on the constructs of the youths' attitude towards mobile marketing. Age was seen to have a positive influence $(\beta=0.041$, t-value $=0.791$, $p$-value $=0.429$ ) on receiving oriented influence. On the other hand, the values for action-oriented attitude, gender and Level of study had a positive influence $(\beta=0.057$, $\mathrm{t}$-value $=1.212$, $\mathrm{p}$-value $=0.225)$ and $(\beta=0.053$, $\mathrm{t}$-value $=$ 1.123 , $\mathrm{p}$-value $=0.261)$ whiles age had negative influence with $(\beta=-0.015$, t-value $=-0.307$, $\mathrm{p}$-value $=0.759)$.

Table 6. Model fit measures

\begin{tabular}{llll}
\hline Measure & Estimate & Threshold & Interpretation \\
\hline CMIN & 31.639 & -- & -- \\
DF & 21 & -- & - \\
CMIN/DF & 1.507 & Between 1 and 3 & Excellent \\
CFI & 0.974 & $>0.95$ & Excellent \\
SRMR & 0.038 & $<0.08$ & Excellent \\
RMSEA & 0.039 & $<0.06$ & Excellent \\
PClose & 0.716 & $>0.05$ & Excellent \\
\hline
\end{tabular}




\section{Discussions}

This study found Innovativeness (INN), Existing knowledge of mobile technology (EKM), Privacy and Permission (PAP), Credibility (CRE), Perceived Risk (PRI), Perceived Value (PVI) and Entertainment (ENT) as factors influencing the youths' action and receiving oriented attitudes towards mobile marketing.

Specifically, the study found that there is the relationship between innovation and the youth's attitude which is positive on both action-oriented and receiving-oriented attitude towards mobile marketing. The study found that the youth see innovation as a tool for mobile marketing and will be happy to receive mobile marketing messages confirming the study by Jeong, Yoo and Heo (2009). The youth have an interest in mobile marketing messages that are credible. This is shown in the study as it was found that there is a positive relationship between credibility and the youths' action oriented and receiving oriented attitude towards mobile marketing (Kushwaha and Shankar, 2013; Thongpapanl,et al., 2018). The youth's receiving and action-oriented attitude towards mobile marketing is largely based on how entertaining the service would be. This is evident in the study as it found a significant positive relationship between entertainment and the youth's attitude (Raines, 2013; Sigurdssona, et al., 2017).

The youth like mobile marketing maybe because of the belief that the risk associated with is very minimal and therefore, they can trust the source of the information. As evident in the study, perceived risk has a positive relationship for receiving but not action as the relationship was negative, Richard and Mandari (2018) indicating that the youth would not want to take action on mobile marketing when they realize that the risk involved is high.

The study found both perceived value and privacy and permission to be positively related to the attitude of the youth towards mobile marketing, an indication that the youth will consider the perceived value of the mobile marketing messages in both receiving and action. The study also realized a positive relationship between privacy and permission and receiving oriented and action-oriented attitude towards mobile marketing messages contrary to Lai, et al., (2018) assertion that the youth will consider privacy and permission before they either accept or take an action. This is an indication that when the youth especially in Ghana are receiving mobile marketing messages, they consider the level of permissions and the privacy issues that come with it.

Finally, this study found that on both receiving and action oriented attitude of the youth, existing knowledge of the service had negative influence contrary to Liu's (2015) argument that the existing knowledge of the customer is crucial to the attitude of the consumer.

The study found a positive relationship between receiving and action oriented attitudes.

\subsection{Managerial Implications}

First, strategically, the new trend of business today is the use of social media to communicate with customers and for that matter, managements need to implement mobile marketing messages that will be accepted and be more interactive with customers. Since customers will be happy receiving the messages, they should be made taking actions based on the massages they receive. Secondly, our research found that the youth consider the value of the messages they receive to be very important and so management of organizations should consider this in the crafting of their messages to the consumers, especially the youth. Finally, this research suggests that managers may have to consider alternative ways of communicating to customers instead of the mainstream communication tools such as TV advertising and look at more innovative ways of using mobile marketing messages to target the youth.

\subsection{Conclusions and Limitations}

The objective of the study was to find out the attitude of the youth towards mobile marketing with emphasis on receiving and action-oriented attitude. The study observed some tools of mobile marketing (Mobile advertising, Mobile entertainment, Mobile sales promotion, Mobile internet, Location-based mobile services, Mobile shopping Mobile banking) that are being used to communicate to target customers and to make mobile marketing a reality.

Finally, the research observed that there were both positive and negative relationships between consumer attitude and consumer factors such as innovativeness, existing knowledge of mobile technology, privacy and permission, credibility, perceived risk, perceived value, and entertainment; and that consumer factors may significantly influence youth's attitude in receiving and taking an action since majority of the consumer factors have a significant relationship with consumer attitude.

This paper contributes to knowledge by developing a conceptual framework which came out of reviewed 
literature that can be used for further studies into the areas of consumer research. The paper looks at new dimensions of attitude such as receiving oriented and action-oriented attitude which to a large extent have been neglected by research in consumer attitude. The limitation is that the study concentrated on only three private and two public universities in Accra, even though there exists a wide range of universities across Ghana. It is also not a fact that the youth can be found only in the universities but also in many other places. Further research could be conducted using the youth who are found in other areas besides the universities and also targeting consumers receiving and action-oriented attitude in larger communities.

\section{References}

Abdul, B. A., Muthu, V. C., \& Phil, M. (2013). Consumer buying behaviour: A literature review. Journal of Business and Management, 1, 8-16.

Abrams, K. V. (2013). UK Digital Trends: Ecommerce, video and mobile thrive, but brands must work for loyalty and trust. Emarketer.

Achieng, B. M., \& Ingari, B. K. (2015). Factors influencing the adoption of mobile banking in Kenya's commercial banks: A case of Kenya Commercial Bank (KCB) Kilindini Branch. International Journal of Scientific Research Publications, 5(10), 1-14.

Acquisti, A., Brandimarte, L., \& Loewenstein, G. (2015). Privacy and human behavior in the age of information. Science, 347 (6221), 509-514. https://doi.org/10.1126/science.aaa1465

Agwu, E., \& Carter, A. L. (2014). Mobile phone banking in Nigeria: Benefits, problems and prospects. International Journal of Business and Commerce, 3(6), 50-70.

Amen, U. (2010). Consumer attitude towards Mobile Advertising. Interdisciplinary Journal of Contemporary Research in Business, 2(3), 75-104.

Arthur, C. (2013). Tablet shipments suggest a crossing point with PCs might not be far off. Retrieved from http://www.guardian.co.uk/technology/2013/feb/01/tablets-crossing-point-pcs

Asongu, S. A., \& Nwachukwu, J. C. (2016). The mobile phone in the diffusion of knowledge for institutional quality in sub Saharan Africa. World Development, 86, 133-147. https://doi.org/10.1016/j.worlddev.2016.05.012

Asongu, S. A., \& Nwachukwu, J. C. (2018). Educational quality thresholds in the diffusion of knowledge with mobile phones for inclusive human development in sub-Saharan Africa. Technological Forecasting and Social Change, 129, 164-172. https://doi.org/10.1016/j.techfore.2018.01.004

Assael, H. (1984), Consumer behaviour and marketing action ( $2^{\text {nd }}$ ed). New York: Kent.

Bakhshi, S. (2012). Impact of gender on consumer purchase behavior. National Monthly Refereed Journal of Research in Commerce \& Management, 9(1), 1-8.

Balan, \& Zegreanum. (2012). The study of consumer attitudes towards mobile marketing practice. Amfiteatru Economic, 14, 786-801.

Banerjee, S., \& Longstreet, P. (2016). Mind in eBay, body in Macy's: Dual consciousness of virtuo-physical consumers and implications for marketers. Journal of Research in Interactive Marketing, 10(4), 288-304. https://doi.org/10.1108/JRIM-05-2015-0036

Baptista, G., \& Oliveira, T. (2015). Understanding mobile banking: The unified theory of acceptance and use of technology combined with cultural moderators. Computers in Human Behavior, 50, 418-430. https://doi.org/10.1016/j.chb.2015.04.024

Barreda, A. A., Bilgihan, A., Nusair, K., \& Okumus, F. (2015). Generating brand awareness in online social networks. Computers in Human Behavior, 50, 600-609. https://doi.org/10.1016/j.chb.2015.03.023

Belanger, F., \& Xu, H. (2015). The role of information systems research in shaping the future of information privacy. Information Systems Journal, 25(6), 573-578. https://doi.org/10.1111/isj.12092

Beldad, A., De Jong, M., \& Steehouder, M. (2010). How shall I trust the faceless and the intangible? A literature review on the antecedents of online trust. Computers in Human Behavior, 26(5), 857-869. https://doi.org/10.1016/j.chb.2010.03.013

Berg, L. P., \& Vance, J. M. (2016). Industry use of virtual reality in product design and manufacturing: A survey. Virtual Reality, 1-17. https://doi.org/10.1007/s10055-016-0293-9

Bock, G. W., Lee, J., Kuan, H. H., \& Kim, J. H. (2012). The progression of online trust in the multi-channel 
retailer context and the role of product uncertainty. Decision Support Systems, 53(1), 97-107. https://doi.org/10.1016/j.dss.2011.12.007

Brooks, F. P. (1999). What's real about virtual reality? IEEE Computer Graphics and Applications, 19(6), 16-27. https://doi.org/10.1109/38.799723

Canalys. (2012). Smart phones overtake client PCs in 2011. Retrieved from http://www.canalys.com/newsroom/smart-phones-overtake-client-pcs-2011

Carroll, A., Barnes, S. J., Scornavacca, E., \& Fletcher, K. (2007). Consumer perceptions and attitudes towards SMS advertising: Recent evidence from New Zealand. International Journal of Advertising, 26(1), 79-98. https://doi.org/10.1080/02650487.2007.11072997

Chang, E. C., \& Tseng, Y. F. (2013). Research note: E-store image, perceived value and perceived risk. Journal of Business Research, 66(7), 864-870. https://doi.org/10.1016/j.jbusres.2011.06.012

Corner, M. D., \& Levine, B. N. (2018, June). MicroMobile: Leveraging mobile advertising for large-scale experimentation (pp. 310-322). In Proceedings of the $16^{\text {th }}$ Annual International Conference on Mobile Systems, Applications, and Services. ACM. https://doi.org/10.1145/3210240.3210326

Evans, S. M., Berry, J. G., Smith, B. J., Esterman, A., Selim, P., O’Shaughnessy, J., \& DeWit, M. (2006). Attitudes and barriers to incident reporting: A collaborative hospital study. BMJ Quality \& Safety, 15(1), 39-43. https://doi.org/10.1136/qshc.2004.012559

Fishbein, M., \& Ajzen, I. (1975). Belief, attitude, intention and behaviour: An introduction to theory and research. Addison-Wesley.

Ghyas, Q. M., \& Kondo, F. N. (2018). Factors influencing intention to use mobile information services among young users: A comparative cross-country study. World Journal of Social Sciences, 8(1), 42-53.

Gopal, R. D., Hidaji, H., Patterson, R. A., Rolland, E., \& Zhdanov, D. (2018). How much to share with third parties? User privacy concerns and website dilemmas. MIS Quarterly, 42(1), 143-164. https://doi.org/10.25300/MISQ/2018/13839

Haron, H., Mun, K. N. K., \& Ahmad, N. (2015). Consumer attitude towards mobile advertising. Advanced Science Letters, 21(5), 1452-1454. https://doi.org/10.1166/asl.2015.6068

Hassan, L. M., Shiu, E., \& Shaw, D. (2016). Who says there is an intention-behaviour gap? Assessing the empirical evidence of an intention-behaviour gap in ethical consumption. Journal of Business Ethics, 136(2), 219-236. https://doi.org/10.1007/s10551-014-2440-0

Heinonen, K., \& Strandvik, T. (2007). Consumer responsiveness to mobile marketing. International Journal of Mobile Communications, 5(6), 603-617. https://doi.org/10.1504/IJMC.2007.014177

Hong, J., \& Im, I. (2018). Captive targeting: A field study on mobile transit advertising. In $39^{\text {th }}$ International Conference on Information Systems, ICIS January 2018. Association for Information Systems.

Hopkins, J., \& Turner, J. (2012). Go mobile: Location-based marketing, apps, mobile optimized ad campaigns, $2 D$ codes and other mobile strategies to grow your business. John Wiley \& Sons.

Informa Telecoms \& Media. (2014). Africa telecoms outlook. Retrieved September 19, 2016, from http://www.informatandm.com

Jang, S. H., \& Lee, C. W. (2018). The impact of location-based service factors on usage intentions for technology acceptance: The moderating effect of innovativeness. Sustainability, 10, 1876. https://doi.org/10.3390/su10061876

Jeddi, S., Atefi, Z., Jalali, M., Poureisa, A., \& Haghi, H. (2013). Consumer behavior and consumer buying decision process. International Journal of Business and Behavioral Sceinces, 3(5), 20-23.

Jeong, N., Yoo, Y., \& Heo, T. Y. (2009). Moderating effect of personal innovativeness on mobile-RFID services: Based on Warshaw's purchase intention model. Technological Forecasting and Social Change, 76(1), 154-164. https://doi.org/10.1016/j.techfore.2008.08.007

Kaan Varnali, A. E. (2012). Mobile marketing research: The-state-of-the-art. International Journal of Information Management, 144-151. https://doi.org/10.1016/j.ijinfomgt.2009.08.009

Katz, R. (2013). Brands need to harness the power of SMS. International Journal of Mobile Marketing, 9(2), 33-35. 
Koksal, M. H. (2016). The intentions of Lebanese consumers to adopt mobile banking. International Journal of Bank Marketing, 34(3), 327-346. https://doi.org/10.1108/IJBM-03-2015-0025

Kondo, F. N., \& Ishida, H. (2014). A cross-national analysis of intention to use multiple mobile entertainment services. Journal of Global Information Technology Management, 17(1), 45-60. https://doi.org/10.1080/1097198X.2014.910991

Kushwaha, T., \& Shankar, V. (2013). Are multichannel customers really more valuable? The moderating role of product category characteristics. Journal of Marketing, 77(4), 67-85. https://doi.org/10.1509/jm.11.0297

Laforet, S., \& Li, X. (2005). Consumers' attitudes towards online and mobile banking in China. International Journal of Bank Marketing, 23(5), 362-380. https://doi.org/10.1108/02652320510629250

Lai, H., Hsu, J. S. C., \& Wu, M. X. (2018). The impacts of requested permission on mobile app adoption: The insights based on an experiment in Taiwan. Proceedings of the $51^{\text {st }}$ Hawaii International Conference on System Sciences. https://doi.org/10.24251/HICSS.2018.490

Latto, J. (2014). Mobile marketing and its implementation. Information Systems Science, 3(4), 16-18.

Lee, T., \& Jun, J. (2007). The role of contextual marketing offer in mobile commerce acceptance: Comparison between mobile commerce users and nonusers. International Journal of Mobile Communications, 5(3), 339-356. https://doi.org/10.1504/IJMC.2007.012398

Li, M., Dong, Z. Y., \& Chen, X. (2012). Factors influencing consumption experience of mobile commerce: A study from experiential view. Internet Research, 22(2), 120-141. https://doi.org/10.1108/10662241211214539

Lin, T. T. C., \& Bautista, J. R. (2018). Content-related factors influence perceived value of location-based mobile advertising. Journal of Computer Information Systems, 1-10.

Liu, Y. (2015). Consumer protection in mobile payments in China: A critical analysis of Alipay's service agreement. Computer Law \& Security Review, 31(5), 1-10. https://doi.org/10.1016/j.clsr.2015.05.009

Logan, K. (2017). Attitudes towards in-app advertising: A uses and gratifications perspective. International Journal of Mobile Communications, 15, 26-48. https://doi.org/10.1504/IJMC.2017.080575

MacKenzie, S. B., \& Lutz, R. J. (1989). An empirical examination of the structural antecedents of attitude toward the ad in an advertising pretesting context. Journal of Marketing, 53(2), 48-65. https://doi.org/10.1177/002224298905300204

Malhotra, N. K., \& Dash, S. (2011). Marketing research an applied orientation. London: Pearson Publishing.

Martin, C. (2013). The mobile shopping life cycle. Harvard Business Review. Retrieved from https://hbr.org/2013/06/the-mobile-shopping-life-cycle

Masamila, B. (2014). State of mobile banking in Tanzania and security issues. International Journal of Network Security \& Its Applications, 6(4), 53. https://doi.org/10.5121/ijnsa.2014.6405

Mayer, R. C., Davis, J. H., \& Schoorman, F. D. (1995). An integrative model of organizational trust. Academy of Management Review, 20(3), 709-734. https://doi.org/10.5465/amr.1995.9508080335

McQuail, D. (1983). Mass communication theory: An Introduction. London: Sage Publication.

Messinger, P. R., Ge, X., Smirnov, K., Stroulia, E., \& Lyons, K. (2019). Reflections of the extended self: Visual self-representation in avatar-mediated environments. Journal of Business Research, 100, 531-546. https://doi.org/10.1016/j.jbusres.2018.12.020

Mitchell, V. W. (1999). Consumer perceived risk: Conceptualisations and models. European Journal of Marketing, 33(1/2), 163-195. https://doi.org/10.1108/03090569910249229

Mobile Marketing Association. (2007). Understanding mobile marketing technology \& reach. Retrieved from http://www.mmaglobal.com

Nakano, S., \& Kondo, F. N. (2018). Customer segmentation with purchase channels and media touchpoints using single source panel data. Journal of Retailing and Consumer Services, 41, 142-152. https://doi.org/10.1016/j.jretconser.2017.11.012

Nikkhah, H. R., \& Sabherwal, R. (2017). A privacy-security model of mobile cloud computing applications. In Thirty Eighth International Conference on Information Systems. San Francisco.

Okazaki, S. (2009). The tactical use of mobile marketing: How adolescents' social networking can best shape 
brand extensions. Journal of Advertising Research, 49(1), 12-26. https://doi.org/10.2501/S0021849909090102

Okello, C., Bongomin, G., Ntayi, J. M., Munene, J. C., \& Malinga, C. A. (2018). Mobile Money and Financial Inclusion in Sub-Saharan Africa: The Moderating Role of Social Networks. Journal of African Business, 19(3), 361-384. https://doi.org/10.1080/15228916.2017.1416214

Persaud, A., \& Azhar, I. (2012). Innovative mobile marketing via smartphones: Are consumers ready? Marketing Intelligence \& Planning, 30(4), 418-443. https://doi.org/10.1108/02634501211231883

Poddar, B., Erande, Y., Chitkara, N., Bhansal, A., \& Kejriwal, V. (2016). Digital and beyond new horizons in Indian banking (pp. 1-43). The Boston Consulting Group, FICCI, Indian Bank's Association, Mumbai.

Raines, C. (2013). In-app mobile advertising: Investigating consumer attitudes towards pull based mobile advertising amongst young adults in the UK. Journal of Promotional Communications, 1(1), 125-148.

Rauschnabel, P. A. (2018). Virtually enhancing the real world with holograms: An exploration of expected gratifications of using augmented reality smart glasses. Psychology \& Marketing, 35(8), 557-572. https://doi.org/10.1002/mar.21106

Rohm, A. J., Gao, T. T., Sultan, F., \& Pagani, M. (2012). Brand in the hand: A cross-market investigation of consumer acceptance of mobile marketing. Business Horizons, 55(5), 485-493. https://doi.org/10.1016/j.bushor.2012.05.004

Rosenblatt, S. (2016). How location-based marketing will evolve in 2017. Retrieved from http://www.adweek.com/brand-marketing/5-ways-location-based-marketing-will-evolve-2017-175204/

Rumanyika, J. D. (2015). Obstacles towards adoption of mobile banking in Tanzania: Review. International Journal of Information Technology and Business Management, 35(1) 485-493.

Sheth, S., \& Kim, J. (2017). Social media marketing: The effect of information sharing, entertainment, emotional connection and peer pressure on the attitude and purchase intentions. GSTF Journal on Business Review (GBR), 5(1).

Sigurdsson, V., Vishnu, M. R. G., Hallgrímsson, A. G., Larsen, N. M., \& Fagerstrøm, A. (2017). Factors affecting attitudes and behavioral intentions toward in-app mobile advertisements. Journal of Promotion Management, 24(5), 1-21. https://doi.org/10.1080/10496491.2018.1405523

Sinkovics, R. R., Pezderka, N., \& Haghirian, P. (2012). Determinants of consumer perceptions toward mobile advertising - a comparison between Japan and Austria. Journal of Interactive Marketing, 26(1), 21-32. https://doi.org/10.1016/j.intmar.2011.07.002

Solove, D. J. (2012). Introduction: Privacy self-management and the consent dilemma. Harv. L. Rev., 126, 1880.

Steuer, J. (1992). Defining virtual reality: Dimensions determining telepresence. Journal of Communication, 42(4), 73-93. https://doi.org/10.1111/j.1460-2466.1992.tb00812.x

Ström, R., Vendel, M., \& Bredican, J. (2014). Mobile marketing: A literature review on its value for consumers and retailers. Journal of Retailing and Consumer Services, 21(6), 1001-1012. https://doi.org/10.1016/j.jretconser.2013.12.003

Thongpapanl, N., Ashraf, A. R., Lapa, L., \& Venkatesh, V. (2018). Differential effects of customers' regulatory fit on trust, perceived value, and m-commerce use among developing and developed countries. Journal of International Marketing, 26(3), 22-44. https://doi.org/10.1509/jim.17.0129

Tsai, W. C. (2012). A study of consumer behavioral intention to use e-books: The technology acceptance model perspective. Innovative Marketing, 8(4), 55-66.

Turban, E., \& King, D. (2003). Introduction to e-commerce. New Jersey: Pearson Education.

Van Bruggen, G. H., Kersi, D. A., \& Jap, S. D. (2010). Managing marketing channel multiplicity. Journal of Service Research, 13(3), 331-340. https://doi.org/10.1177/1094670510375601

Varshney, S., \& Joy, J. (2015). Consumer attitudes toward mobile marketing and its impact on customers. International Journal of Information, Business, and Management, 7(2), 44-62.

Wang, Y., \& Chen, H. (2019). The influence of dialogic engagement and prominence on visual product placement in virtual reality videos. Journal of Business Research, 100, 493-502. https://doi.org/10.1016/j.jbusres.2019.01.018 
Wu, L., \& Stilwell, M. A. (2018). Exploring the marketing potential of location-based mobile games. Journal of Research in Interactive Marketing, 12(1), 22-44. https://doi.org/10.1108/JRIM-06-2017-0041

Yim, M. Y. C., \& Park, S. Y. (2019). "I am not satisfied with my body, so I like augmented reality (AR)": Consumer responses to AR-based product presentations. Journal of Business Research, 100, 581-589. https://doi.org/10.1016/j.jbusres.2018.10.041

Zabadi, A., Shura, M., \& Elsayed, E. (2012). Consumer attitudes toward SMS advertising among Jordanian users. International Journal of Marketing Studies, 4(7), 77-94. https://doi.org/10.5539/ijms.v4n1p77

\section{Copyrights}

Copyright for this article is retained by the author, with first publication rights granted to the journal.

This is an open-access article distributed under the terms and conditions of the Creative Commons Attribution license (http://creativecommons.org/licenses/by/4.0/). 